IZA DP No. 5930

Taxes, Wages and Working Hours

Peter Ericson

Lennart Flood

August 2011

Forschungsinstitut zur Zukunft der Arbeit Institute for the Study of Labor 


\title{
Taxes, Wages and Working Hours
}

\author{
Peter Ericson
}

Sim Solution

Lennart Flood

University of Gothenburg

and IZA

\section{Discussion Paper No. 5930 \\ August 2011}

\author{
IZA \\ P.O. Box 7240 \\ 53072 Bonn \\ Germany \\ Phone: +49-228-3894-0 \\ Fax: +49-228-3894-180 \\ E-mail: iza@iza.org
}

Any opinions expressed here are those of the author(s) and not those of IZA. Research published in this series may include views on policy, but the institute itself takes no institutional policy positions.

The Institute for the Study of Labor (IZA) in Bonn is a local and virtual international research center and a place of communication between science, politics and business. IZA is an independent nonprofit organization supported by Deutsche Post Foundation. The center is associated with the University of Bonn and offers a stimulating research environment through its international network, workshops and conferences, data service, project support, research visits and doctoral program. IZA engages in (i) original and internationally competitive research in all fields of labor economics, (ii) development of policy concepts, and (iii) dissemination of research results and concepts to the interested public.

IZA Discussion Papers often represent preliminary work and are circulated to encourage discussion. Citation of such a paper should account for its provisional character. A revised version may be available directly from the author. 


\section{ABSTRACT}

\section{Taxes, Wages and Working Hours*}

This paper presents estimates of individuals' responses in hourly wages to changes in marginal tax rates. Estimates based on register panel data of Swedish households covering the period 1992 to 2007 produce significant but relatively small net-of-tax rate elasticities. The results vary with family type, with the largest elasticities obtained for single males and the smallest for married/cohabitant females. Despite these seemingly small elasticities, evaluation of the effects of a reduced state tax using a microsimulation model shows that the effort effect matters. The largest effect is due to changes in number of working hours yet including the effort effect results in an almost self-financed reform. As a reference to the earlier literature we also estimate taxable income elasticities. As expected, these are larger than for the hourly wage rates. However, both specifications produce significantly and positive income effects.

\section{NON-TECHNICAL SUMMARY}

Many studies of the behavioral effects of taxes assume that individuals only response is in working hours. This paper extends the behavioral effects to also include change in hourly wage rates. A decrease in tax rates may also affect the willingness to accept a management position, working inconvenient hours, moving to a higher paid job or investing in human capital. An evaluation of a decreased state tax in Sweden shows that both the labor supply and hourly wage effects are important. Including both effects indicate that the dynamic effects are so large that the reform is financed up to almost 80 percent.

JEL Classification: $\quad \mathrm{C} 8, \mathrm{D} 31, \mathrm{H} 24, \mathrm{~J} 22, \mathrm{~J} 31$

Keywords: income taxation, hourly wage rates, work effort, micro simulation

Corresponding author:

Lennart Flood

School of Business, Economics and Law

University of Gothenburg

P.O. Box 640

SE 40530 Göteborg

Sweden

E-mail: Lennart.Flood@economics.gu.se

\footnotetext{
* Financial support from the Confederation of Swedish Enterprise, Riksbankens Jubileumsfond and Ragnar Söderbergs Stiftelse is gratefully acknowledged.
} 
Feldstein (1995 and 1999) broadens the analysis of taxes beyond the traditional measures of labour supply. In this broader approach the key variable is taxable income and the argument is that the response of this variable to the income tax rate captures all of the important responses to taxation. Meghir and Phillips (2009) refer to this approach as "the new tax responsiveness literature" and provide a short review of the main findings; the studies based on the broader income measure often produce larger or even much larger incentive effects compared to those found in the traditional labour supply literature.

In contrast to the findings in the international literature, studies based on Swedish data often report lower tax responses; see Gelber (2008), Hansson (2007), Holmlund and Söderström (2008), Ljunge and Ragan (2006) and Selén (2005). An interesting contribution is given by Blomquist and Selin (2008), who not only focus on a broader income measure but also use hourly wage rate as an alternative. Based on a sample from 1981 to 1991 on married males and females, they obtain large net-of-tax elasticities for females - in the range of 1-1.4 for taxable income and about half that size for hourly wages.

The main purpose of our paper is to estimate hourly wage rate elasticities and to use these estimates together with labour supply responses for a tax policy evaluation. The tool for the evaluation is a microsimulation model, SWEtaxben, developed in order to evaluate the impact of tax and benefit changes on Swedish household; see Ericsson and Flood (2009). Since models for labour supply are already implemented in SWEtaxben, this paper concentrates on the estimation of hourly wage effects. Apart from presenting estimates on hourly wage rates, results based on taxable income are included as a reference to earlier work. In contrast to Blomquist and Selin, who used survey data from 1981 to 1991, our data are based on a large register based panel from 1992 to 2007.

The evaluated reform consists of a reduction in the state tax (central governmental tax) - before the reform about 20 percent of the taxpayers paid this tax and we increase the tax brackets so that only about 10 percent do so after the reform. The evaluation is presented as a pure static, or first-round effect, as well as a second-round effect allowing for behavioural changes. The second-round effect is decomposed into an effect on hours of work as well as on hourly wages. According to the results, the wage (effort) effect matters but is smaller than the labour supply effect.

Section 2 below presents a short review of the literature on the net-of-tax elasticity for different income variables including one study based on hourly wages. The focus is on the 
papers using Swedish data. Section 3 describes our data and also includes a description of changes in wages, working hours and taxes during the period of estimation. Section 4 presents the model and the method used for estimation and also includes the results given as net-of-tax and virtual income elasticities. Section 5 gives a short description of the microsimulation model SWEtaxben (Swedish tax/benefit model) used for the policy evaluation. Section 6 summarizes the evaluation of a decreased state tax. The final section summarizes the results. An appendix presents results based on similar methods as in Blomquist and Selin.

\section{Previous work}

A recent review of the "new" literature is given in Meghir and Phillips (2009) and in Saez et al. (2009). Table 1 below provides a subsample of the studies discussed in these sources.

Although not the first study, Feldstein (1995) set the standard for many studies to follow. His variable of interest is based on taxable income and he utilizes a two-period panel of married couples to analyse the impact of the 1986 US tax reform. Arguing that the tax reform could be regarded as a natural experiment, he uses a standard difference-in-differences technique. His results indicate large tax responses - an elasticity of taxable income between 1.1 and 3.05, the largest effect being for individuals with higher income.

Sillamaa \& Veall (2000) based their study on a Canadian tax reform. Their main contribution is a detailed breakdown by source of income, and the results demonstrate a lack of robustness. Using taxable income based on employment produced an elasticity of 0.22 and the corresponding result for income from self-employment was over one. Further, selecting the sample based on higher income produced elasticities well above one.

Goolsbee (2000) verified the lack of robustness in another dimension, namely the kind of reform evaluated. He used the same approach for a number of US reforms from 1922 to 1989 , and the elasticity varies considerably across the different reforms.

According to Meghir and Phillips, the paper by Gruber and Saez (2002) represents the most comprehensive study in this literature and discusses several potential problems. Firstly, the data span a large number of different US reforms. Secondly, they use past income as a way of getting around the mean reversion problem, i.e. that individuals adjust their initial income regardless of changes in taxes, and they also predict the tax rate based on past income as an instrumental variable. Thirdly, they include controls for the increasing income distribution and finally they derive an income effect in close analogy with the structural 
labour supply approach. The results show a taxable income elasticity of 0.4 on average and 0.57 for high income earners.

(Table 1 about here)

Saez et al. (2009) presents a number of studies based on Swedish data, below in Table 2, we extend the list and to the best of our knowledge this table covers all available studies. One reflection is that there is a surprisingly large amount of recent papers based on Swedish data. One reason for this might be access to high-quality register data and another is that Sweden has experienced such dramatic changes in the tax systems, the prime example being the major tax reform in 1991. All studies, except one, are based on the administrative LINDA data and most of them utilize the 1991 "tax reform of the century" to identify tax responses.

Sélen (2002) uses similar methods as in Feldstein (1995) but is much more ambitious concerning test of robustness. A large number of different income definitions and model specifications are evaluated and also an income effect is estimated. The estimated net-of-tax elasticity for a specification including initial income as well as an income effect is 0.41 and the corresponding income elasticity is 0.27. Ljunge \& Ragan (2006) use earned income and estimate a static and dynamic model also both extensive as well as intensive margins are included. They report large responses to the 1991 year tax reform, with elasticities of about 0.35 on the intensive margin. Hansson (2007) estimates the elasticity of earned taxable income using two different approaches and a number of control variables and the 1991 tax reform. The elasticity estimates for the preferred specification fall in the range of $0.4-0.5$.

Gelber (2008) uses a family model, where spouses consider each other's net-of-tax rates, and analyze responses to the 1991 reform. The estimates imply that husbands' and wives' leisure are complements. They test and reject the standard labour supply specification, in which one spouse reacts to the other spouse's income as if it were unearned income. Holmlund \& Söderström (2008) use a panel including the 1991 reform but also a period thereafter. They estimate dynamic models and differ between short-run and long-run effects. The estimates of the long-run elasticity of income with respect to the net-of-tax rate are in the range of 0.2-0.3 and the short-run elasticities are smaller. An interesting contribution is that they do not stop at estimation elasticities but also use these for a tax reform evaluation. Due to the dynamic effects a reduction of the top marginal tax rate by five percent does not decrease tax revenues.

Blomquist \& Selin (2008) use a panel data set from 1981 to 1991. This period covers a number of tax reforms thus providing a rich variability (decrease) in marginal tax rates. An important contribution is the derivation of virtual income, which provides a closer link to a 
structural model, and this is also the only study that, apart from taxable income, uses hourly wage rate as the dependent variable. An alternative definition of instrumental variables, to account for the endogeneity of marginal tax rates, is also suggested. The hourly wage rate elasticity with respect to the net-of-tax rate is estimated to $0.14-0.16$ for males and $0.41-0.57$ for females. The uncompensated taxable labour income elasticities are 0.21 for men and 0.961.44 for women.

(Table 2 about here)

All the studies, with one exception, cover a similar period - before the tax reform and most often a short period thereafter. This might be a reason why the net-of-tax rate results seem to be rather stable, around 0.2-0.5, across the studies. The exception is Blomquist and Selin, who obtain much larger effects for women. Possible explanations are that they use different data with a much smaller sample size but also a different choice of instrument as well as an alternative definition of virtual income. Also, note the small effects obtained by Holmlund and Söderström. This result is obtained despite the fact that they focus on highincome (above median) earners. A plausible reason is that they use data covering a period after the 1991 reform. The tax variation after the reform was much smaller than before, and the major change in the tax system utilized by Holmlund and Söderström was the increase in the top marginal tax rate by five percentage points in 1995 .

The next section presents the data used in our study, introduces important definitions and presents descriptive statistics.

\section{Wages, hours and taxes - definitions and stylized facts}

Access to income and hourly wage data of high quality is a prerequisite for this kind of analysis and we argue that this request is fulfilled in an almost ideal way by the LINDA register data. ${ }^{2}$ Since measurement of hourly wages plays a crucial role, a detailed description of this variable is provided. The starting point is information about individuals' monthly income given a full working-time contract; this information is provided by the employer. Next, hourly wage rate is obtained by dividing the measure of monthly income by number of working hours, given a standard full-time contract (165 hours per month). Thus, our measure of hourly wages does not suffer from measurement errors which would be the case had we divided by a measure of self-reported working hours. Measurement errors in hours would then

\footnotetext{
${ }^{2}$ See Edin and Fredriksson (2000).
} 
spill over to errors in wage rates and cause a spurious correlation between wages and hours. ${ }^{3}$ In contrast, the measure used here is not vulnerable to this problem, since we use a constant as a divisor, i.e. 165. Thus, any remaining measurement errors in hourly wage rate should be uncorrelated to measurement errors in working hours.

Apart from wages (W) we also construct yearly working hours (H). Two sources of information are available: information from the employer and information on yearly earnings from administrative tax registers. Information from the employer gives the working hour's contract expressed as a percentage of a full-time contract. A problem with this measure is that it is not directly related to actual working hours. The implication is that there is very little variation especially in male working hours. For this reason the measure of hours used in this paper is obtained by dividing the measure of annual labour income $\left(\mathrm{W}^{*} \mathrm{H}\right)$ by the wage rate (W).

Despite the advantage of our data there are also some potential problems. As mentioned above the wage information is given by the employer and there is a low degree of nonresponse. Since this non-response is concentrated to employers with few employees, this causes a potential problem of selectivity. For instance, self-employed can be more responsive towards economic incentives; see Blow and Preston (2002). It seems reasonable that underrepresenting small firms or self-employed implies underestimating the responsiveness of changes in tax and benefits. Another problem is that the information from the employers has been collected during one month in contrast to the annual measure of income. Of course conditions might have changed during the year, e.g. an individual might have changed jobs or working hours. This could create a problem with our measures of both $\mathrm{W}$ and $\mathrm{H}$. To reduce this problem a restriction has been imposed implying that individuals with large differences in income according to the two utilized sources of information, i.e. the employer's records and the tax registers, have been deleted. Also for this reason individuals working very long hours have been dropped, by using a limit of 4000 hours/year (however, very few individuals are excluded for this reason). Given these caveats our claim is that the measures of $\mathrm{W}$ by construction provide an almost ideal base for the study of effects on taxes.

Another advantage of the data used is that they form a panel. Since there is no problem of non-response in LINDA, attrition is not a problem. Furthermore, LINDA represents a random sample of almost three percent of the Swedish population. This sample size is an

\footnotetext{
${ }^{3}$ For a presentation of measurement problems in working hours, see Selén (1995).
} 
important advantage in the estimation methods used, especially regarding the possibility of choosing valid instruments.

Since the main idea is to study the effect of taxes on effort, individuals who work short hours, less than 1000 hours/year or not at all, have been excluded. Note that number of working hours has been used for these selections but is not used in the model that has been estimated. After these selections, an unbalanced panel where an individual must be included in an uninterrupted sequence of at least three years, from 1992 to 2007, has been created, including a total of almost 700000 observations.

The data used span a different period compared to in Blomquist and Selin. They used data before and after the major Swedish tax reform in 1991 and utilized only two time periods, i.e. 1980 and 1991, for the estimation (however an intermediate year was used for obtaining a measure of taxable income). There are both pros and cons to these two approaches. We use a much larger sample of annual data that covers a longer period but do not include a dramatic tax change. The introduction of an in-work tax credit in 2007 might be considered as a large tax change, yet is not at all comparable to the tax reform in 1991. Thus, the reform in 1991 can help identify the tax effect but at the same time such a reform represents something extraordinary and this can also create a problem. The reform in 1991 has been called "the tax reform of the century" and covered a whole range of tax changes and not only income taxes. It is not obvious that such a dramatic change is ideal if the purpose is to estimate parameters that are used for predicting future responses to changes in a tax and benefit system. On the other hand the tax changes after the reform have been more modest and this might create a problem of identifying any effects at all from the tax system. However, using data from such a long period still includes a lot of changes and we argue that this variation provides us with enough information. For a detailed description of the changes in the tax system during this period, see Tax Statistical Yearbook of Sweden (2007) and Hansson (2006). The most important changes are mentioned below.

Figure 1 shows the distribution in working hours in 2007. Note that the lower and upper cut-off points at 1000 and 4000 respectively have only a minor effect. As expected, females have a higher frequency of lower hours and males of higher hours.

(Figure 1 about here)

Figure 2 shows the corresponding information for hourly wage rates. Again the shape is as expected - a higher frequency of high wages for males and a higher concentration of females in the lower wage range. No lower cut-off has been used but all wages higher than 
600 SEK have been deleted. Of course the influence of this upper wage truncation has been tested in our estimates and as expected the effect is very small.

(Figure 2 about here)

Table 3 shows the average levels for some of the variables of importance, and Figure 3 presents the rate of changes in these variables. Note the strong increase in real wages, almost 50 percent, from 1992 to 2007 . These rates are similar regardless of gender, but as shown in Table 3 the level is higher for males. In 1992 the mean number of yearly working hours was 2152 for males and 1811 for females. Figure 3 shows decreasing hours for males and an increase for females. By comparison to labour force survey data, these figures might seem high and it might also look surprising that the recession in the early 1990s did not have much effect. However, the sample used for the analyses comprises individuals working at least 1000 hours a year. The decrease in working hours for males after 1995/96 must be explained by other factors than the business cycle. For females the trend is increasing and also for the last years it is increasing for males as well.

(Table 3 about here)

The change in marginal tax rates depends mainly on changes in labour income and changes in tax rules. In 1992 the mean marginal tax rate was about 41 percent for males and almost 35 percent for females. The changes displayed in Figure 3 show a strong increase for females reaching a peak in 1999 and for males a few years earlier. This is partly explained by the increase in taxes due to a political agreement following the severe recession in the early 1990s but also to "bracket creep", i.e. more individuals are exposed to higher tax brackets as a result of inflation. Other important changes include the introduction of a social security contribution in 1993 and an increase of the highest state tax to 25 percent in 1995. After this initial period of increased taxes and social contributions a long period follows with gradually decreasing taxes. In 2007 an in-work tax credit was introduced, which explains the drop in marginal tax rate displayed in Figure 3.

(Figure 3 about here)

The importance of an increasing income distribution has been stressed in the literature. It is possible that an increase in taxation is caused by an increase in the highest income, and if this increase is caused by factors unrelated to taxes, then this must be controlled for in the estimation. In order to demonstrate the importance of this argument, Figure 4 displays the change in wage distribution. The two upper lines show the $90^{\text {th }}$ percentile divided by the $10^{\text {th }}$, with the upper line for males and the lower for females. Thus, in 1992 the male wage rate at the $90^{\text {th }}$ percentile was about 1.9 times higher than at the $10^{\text {th }}$ percentile and in 2007 this ratio 
had increased to about 2.2, yielding an increase by 14.5 percent; the corresponding increase for females was 18.4 percent. Measured as the ratio of the third and first quintile the increase is smaller, 6.9 and 8.1 for males and females, respectively.

(Figure 4 about here)

Figure 5 displays the covariation of hourly wages and working hours. Working hours are ranked from decile one to decile ten and the average hourly wage rate has been calculated for each decile. It follows that the wage levels are much lower at working hours in decile one compared to decile ten. For females there is a clear trend, the wage rate increases with working hours. For males this pattern is not so clear, note for instance the high level of male wages at the third decile.

(Figure 5 about here)

The next section explains the statistical model for estimation of wage (and taxable income) elasticities.

\section{The hourly wage rate model}

The traditional labour supply literature regards the hourly wage rate as given and analyses only the hours of work response. However, there are many reasons why hourly wages may change as a result of changes in taxes. Instead of working hours, the "new" literature focuses on the effort dimension. An individual can increase his effort but still work the same number of hours. The increased effort can take different forms, such as accepting a management position, accepting working inconvenient hours, moving to a higher paid job or investing in human capital. The purpose of the model derived in this section is to estimate the individual response to changes in net-of-tax and virtual income on hourly wage rate. The assumption is that this effect captures the effort dimension.

Gruber and Saez (2002) derived a taxable income model analogous to a traditional labour supply model. An individual maximizes utility by choosing consumption, $\mathrm{C}$, and taxable income, $\mathrm{I}$, subject to a budget constraint $\mathrm{C}=(1-\mathrm{t}) \mathrm{I}+\mathrm{y}$, where $\mathrm{t}$ is marginal tax rate on a linear segment and y is virtual income on that same segment. Virtual income represents the intersection of the individual's extended budget segment in consumption-effort space with the $\mathrm{Y}$-axis. The optimal solution expresses taxable income as a function of net-of-tax rate and virtual income. Blomquist and Selin modified this approach by defining virtual income analogously to the labour supply literature assuming a piece-wise linear budget set. 
The model used for the analysis of hourly wage rate resembles the model for taxable income (for details see Blomquist and Selin). As a starting point, assume that individuals maximize utility according to $\mathrm{U}=\mathrm{U}(\mathrm{C}, \mathrm{E}, \mathrm{H})$, where $\mathrm{E}$ is effort and $\mathrm{H}$ hours of work. Taxable income in the budget constraint above is replaced by a wage function multiplied by hours, where the wage function, $\mathrm{w}(\mathrm{E}, \mathrm{z})$, is a function of effort and individual characteristics $\mathrm{z}$.

The optimal wage rate is derived as a linear approximation of net-of-tax rate and virtual income. Including individual characteristics $\mathrm{z}$, the wage equation is given as

$$
\ln \left(\mathrm{W}_{\mathrm{it}}\right)=\beta_{1} \ln \left(1-\mathrm{t}_{\mathrm{it}}\right)+\beta_{2} \ln \left(\mathrm{y}_{\mathrm{it}}\right)+\beta_{3} \mathrm{z}_{1 \mathrm{it}}+\ldots+\beta_{\mathrm{k}} \mathrm{z}_{\mathrm{kit}}+\varepsilon_{\mathrm{it}}
$$

where $\mathrm{W}$ denotes gross wage rate and the z-variables apart from individual characteristics also include time effects. We use a somewhat different definition of virtual income than Blomquist and Selin and write $y=$ WHt-T, where $\mathrm{T}$ is total $\operatorname{tax}^{4}$. Given data that include enough variation in taxes, the parameters can be estimated and the parameters of importance, $\beta_{1}$ and $\beta_{2}$, produce the net-of-tax and virtual income elasticities.

Meghir and Phillips (2009) summarize many of the challenges that have to be solved in order to provide reliable estimates. An obvious challenge is caused by the fact that effort in contrast from working hours cannot be observed, which prevents estimation of structural models based on economic theory. A common method of estimation is based on "differencein-difference" and ideally, given the assumption of a natural experiment, any significant difference can be interpreted as a causal effect, i.e. that a change in taxes has caused a change in taxable income (or hourly wage rates).

Unfortunately, tax reforms are often not in accordance with the assumption underlying a natural experiment. A tax change often applies to all taxpayers and there is no control group. Instead all individuals are part of the treatment group, and this causes considerable problems both in estimation and in interpretation. ${ }^{5}$ The practical implementation of the difference-indifference method becomes a comparison before and after a tax change. The control group comprises all individuals before the change and the treatment group the same individuals after the change.

The approach used in this paper is not based on the difference-in-difference method but is instead closely related to the method used in Gruber and Saez (2002). They used an

\footnotetext{
${ }^{4}$ For details, see MaCurdy et al. (1990).

${ }^{5} \mathrm{~A}$ review of the literature is given in Imbens and Wooldridge (2009). For a critical assessment, see e.g. Deaton (2009).
} 
unbalanced panel covering several different reforms and then constructed changes between pairs of years. They used a three-year time difference and stacked all these differences into one single dataset. In contrast, as our baseline approach we construct an unbalanced panel from 1992 to 2007 and use fixed effect estimation.

Gruber and Saez highlight the importance of controlling for secular changes in the income distribution. One reason is mean reversion - high (low) incomes in the initial year tend to be lower (higher) in the following year, producing a negative (positive) correlation between the error term and income during the first year. The second reason is that an increase in the distribution of income (in our case hourly wages) implies higher taxes. Thus, if there is a trend towards an increasing income (wage) distribution for reasons other than changes in taxes, this will lead to an increase in the number of individuals with high taxable income and, thus, due to the progressivity in the income tax system to more people paying high marginal tax rates. This correlation between the error term and income (wages) causes a problem. It is therefore necessary to include control variables in the regression. One suggestion has been to include lagged income and also a spline function in first period income. The knots in the spline are the income levels at the different deciles. Here we use dummy variables to control for income and wage decile in the initial year, and time dummies are also included.

Apart from the problem of mean reversion and increased income distribution there is also a problem of endogeneity. The net-of-tax rate as well as virtual income is a function of the dependent variable. The standard statistical method to solve this problem is to use instrumental variables. To define these instruments is a major challenge that occupies a large part of "the new tax responsiveness literature".

Two variants of instruments have been used in the present paper: lagged taxable income and predicted taxable income. Flood (1990) and Klevmarken (2000) suggested the use of lagged instead of current taxable income as an input for the tax calculations. The motivation apart from reducing the problem of endogeneity was that individuals do not know the current income until the end of the year, but instead use last year's taxable income as a proxy in their tax calculations. However, since there is a high degree of inertia in taxable income, the main problem of endogeneity remains. As a result, an alternative definition was suggested in Carlin and Flood (1997), i.e. taxable income was calculated based on a predicted wage rate. The wage model utilized only individual and household characteristics, which solves or at least reduces the endogeneity problem. The recent "new tax responsiveness literature" has often used instruments that are functions of lagged taxable income, typically taxable income from the first time period. 
Blomquist and Selin use a similar approach as Carlin and Flood and predict taxable income using exogenously individual/household variables but add to this a taxable income with a five year time difference. The first time period in Blomquist and Selin is 1981 and the last is 1991 , and they use a measure of taxable income in the middle of this period, i.e. from 1986.

A possible drawback of using previous or later (with a long time difference) measures of taxable income is that this requires a balanced panel. A balanced panel covering a long period implies a non-representative cross-sectional sample. This problem would be serious in our approach since several household types will be estimated separately, for instance a long panel of single mothers creates a selective sample that creates problems of inference. In order to avoid this, our models are estimated based on an unbalanced panel. As a consequence, the predicted taxable income is based only on individual/household specific variables and no measure of previous or future taxable income is used. A taxable income model is estimated annually using as independent variables age, education, region, household composition and also interaction between some of these.

To summarize, the following instruments have been tested: (1) current year taxable income $\left(\mathrm{I}_{\mathrm{t}}\right)$, (2) with one year lag $\left(\mathrm{I}_{\mathrm{t}-1}\right),(3)$ two years lag $\left(\mathrm{I}_{\mathrm{t}-2}\right)$ and $(4)$ predicted taxable income $(\hat{I})$. Of all these alternatives we only present the results based on the last method. The reason is that this method should minimize the problem of endogeneity.

In order to allow for heterogeneity in the parameters, separate models have been estimated for different family types: single mothers, single females and males and married/cohabit female and males. Individual and household characteristics such as age, age squared, education, interaction age and education, region, number of children and also age of children are included. The baseline method of estimation is fixed effects.

The estimated parameters, presented in Table 4, show a large variation in net-of-tax rate and virtual income elasticities among the different family types. Single-headed households have larger net-of-tax rate elasticities compared to married/cohabit. The strongest effect is obtained for single males (0.16) followed by single females $(0.14)$ and single mothers $(0.09)$. For married males the elasticity is smaller (0.05) and for females it is essentially zero. The virtual income elasticity is positive but small for all family types.

(Table 4 about here)

How does our estimates compare to other results in the literature. To the best of our knowledge, the only reference using hourly wages is Blomquist and Selin. A comparison for married males and females shows that our estimated net-of-tax elasticities are much lower and 
also that the virtual income elasticities are much larger. However there are many possible reasons for these differences and in Appendix II an attempt is made to replicate the results using similar methods as in Blomquist and Selin. The differences still remain and one possible reason is that we use a different period that does not include large marginal tax reductions and the impact of the tax reform 1991.

Since most of the results in the literature are based on taxable income instead of hourly wages, Table 5 presents estimates of the taxable income elasticities. As expected, the estimated net-of-tax elasticities are larger than for the hourly wage model. All single-headed households have elasticities in the range of $0.4-0.5$. The figure is 0.11 for married/cohabitant males and, as before, almost zero for females. Ljunge and Ragan report an elasticity of 0.35 (all individuals age 25-55, Linda data for the period 1989 to 1994 and Blomquist and Selin report 0.21 for males and 0.96-1.44 for females (married age 25-55, survey data for the time period 1981-1991).

(Table 5 about here)

In order to verify the robustness of our results, Table 6 presents the estimated elasticities for several alternative specifications. The first column presents the results of the baseline model, fixed effect estimation. In column 2 the model is estimated using random effects, and the main difference is somewhat larger elasticities. One reason for this difference could be lack of controls for unobserved heterogeneity. In accordance with the suggestion in Wooldridge (2002), we include the lagged dependent variable as a proxy for unobserved heterogeneity. The results in column 3 produce smaller elasticities compared to the baseline results without the lagged dependent variable, but the difference is not dramatic. In column 4 estimation of the dynamic specification is repeated but now using random effects. As confirmed by comparing columns 3 and 4, random effects and fixed effects produce approximately similar results. Next, we introduce controls for mean reversion by using initial values of the dependent variables. Since these variables have a high degree of collinearity with the lagged dependent variables, our specification includes only initial values instead of lagged ones. The results in column 5 are similar to the lagged dependent variables specification. Apart from mean reversion it is also important to include controls for changes in the distribution of income or wages. For this purpose, dummy variables are constructed measuring what decile the individual belonged to during the initial year. The results in column 6 are similar to the corresponding results without these dummy variables. Finally, since many papers report results based on balanced panels, column 7 presents the elasticities for a model including initial values and decile dummies but using a balanced panel. There is no dramatic 
difference caused by using a balanced panel. Note the similarity of these elasticities and the ones obtained for the baseline model. To conclude, the variation across models is relatively small.

(Table 6 about here)

Even if the size of the elasticities is informative it is still difficult to draw conclusions regarding the effects of changes in the tax and benefit rules. In order to evaluate these effects, the microsimulation model SWEtaxben will be used. This model will be explained below, but let us first briefly describe the data used for estimation.

\section{SWEtaxben - a microsimulation model for the Swedish household}

Relating to the micro simulation literature, SWEtaxben can be labelled as a static micro simulation model with behavioural changes. Behaviour changes are measured in two dimensions, i.e. number of working hours and hourly wages (added in this paper). For working hours the behavioural response takes two different forms and uses two different types of models: first binary models that describe mobility in/out from non-work states such as old age pension, disability, unemployment, long term sickness, and second models that describe change in working hours and welfare participation. Thus, apart from the choice to work or not to work (extensive margin), working hours conditional on working (intensive margin) as well as welfare participation are treated as endogenous variables. For the wage dimension the responses are simulated using the estimated elasticities presented in this paper.

The data used for the simulations are based on the 2007 LINDA, from Statistics Sweden. The sample size corresponds to almost 8 percent of the Swedish population, thus, all the output is given with a high precision and, since the sampling weights are known, aggregate population measures can be produced.

The tax/benefit part of SWEtaxben is primarily a tool to calculate the households' budget set. For the two-earner household the budget (disposable income or net income after tax and transfers) evaluated at observed working hours is given as

$$
\mathrm{C}=\mathrm{I}_{\mathrm{m}}+\mathrm{I}_{\mathrm{f}}+\mathrm{B}_{\mathrm{s}}+\mathrm{B}_{\mathrm{h}}-\mathrm{B}_{\mathrm{c}} \quad \text { where } \mathrm{I}_{\mathrm{i}}=\mathrm{W}_{\mathrm{i}} \mathrm{H}_{\mathrm{i}}+\mathrm{Y}_{\mathrm{i}}+\mathrm{V}_{\mathrm{i}}-\mathrm{t}\left(\mathrm{X}_{\mathrm{i}}\right), \mathrm{i}=\mathrm{m} \text { (male), } \mathrm{f} \text { (female) }
$$

Apart from hourly wages, $\mathrm{W}_{\mathrm{i}}$, and yearly number of working hours, $\mathrm{H}_{\mathrm{i}}, \mathrm{Y}_{\mathrm{i}}$ represents nonearned taxable income (e.g. capital income, old age pension and benefits from unemployment, disability and long term sickness) and $\mathrm{V}_{\mathrm{i}}$ non-earned non-taxable income (e.g. child allowance); $t$ is a tax function defined on taxable income, $X_{i},\left(X_{i}=W_{i} H_{i}+Y_{i}-D_{i}\right.$ where $D_{i}$ is deductions for work-related expenses or part of the premium for private pension savings). The 
three means-tested (i.e. dependent on $\mathrm{H}_{\mathrm{i}}$ ) transfers considered are social assistance $\left(\mathrm{B}_{\mathrm{s}}\right)$, housing allowance $\left(\mathrm{B}_{\mathrm{h}}\right)$ and cost of child care $\left(\mathrm{B}_{\mathrm{c}}\right)$. It is a considerable advantage that these systems are based on nationwide rules.

In order to understand the sequential steps involved in the simulation, it is instructive to start by dividing the sample into the following subgroups:

(1) Child, age 0-15, (2) Old age pensioner, age 61-, (3) Student, (4) Disability pensioner, age 18-64, and old age pensioner after 64, (5) Parental leave, (6) Unemployed, age 18-64 and old age pensioner after 64, (7) Other (no income from states 2-6, 8, 9 but can have income from social assistance), (8) Long-term sick, age 18-64, and old age pensioner after 64 and (9) Working, age 18-70, and old age pensioner after 70 .

This classification refers to a full time status during the base year (2007) and is primarily based on the main source of income. Individuals who got their main income from old-age pension are classified as pensioners, and so on. There are also some age related criteria that overrule the income source. Thus, all individuals younger than 16 are classified as child, and all individuals above 70 as old age pensioner. An individual can only be classified as disabled, unemployed or long-term sick up to age 64; above this age he is classified as an old age pensioner.

The main sequential steps are given in Figure 6. The first step (see Figure 6) involves the definition of a replacement rate for disability pension. The population at risk comprises individuals age 18-64 (but not older children living together with their parents) with a status of disabled/unemployed, long-term sick or working. For couples, at least one of the spouses has to belong to the population at risk. For each individual in this population, the tax/benefit module is called upon to calculate disposable income assuming that everyone is classified as being on full-time disability. Next, for the same individuals, income is calculated assuming full-time work $(\mathrm{H}=1800)$. The ratio disposable income from disability divided by disposable income from work defines the replacement rate. For instance, a replacement rate of 0.7 means that an individual who receives full-time compensation from disability insurance receives 70 percent of the disposable income he would have received had he been a full time worker. A change in a tax/benefit that has an effect on the replacement rate will also have an effect on the probability of entering, staying in, or exiting from disability.

(Figure 6 about here)

Given the replacement rate, as well as all other explanatory variables included in the model, the probability of disability is calculated. In the calculation of this probability two stochastic terms enter: first a random draw from a normal distribution (with an estimated 
mean and variance) representing individual heterogeneity and second a Monte Carlo experiment. If the simulated probability is less than a random draw from a uniform (0-1) distribution, then the event takes place; i.e. the individual is classified as disabled. Individuals not classified as disabled get the temporary status (10) and enter the next stochastic model in the sequence. Note that the random errors for each individual are the same before and after a reform. The Monte Carlo experiment acknowledges the fact that even individuals whose characteristics are such that the likelihood of disability are very low still face the risk of "bad luck". With appropriate changes the same argument also applies to an individual with a high systematic probability of disability. This stochastic experiment has been applied to all binary events in the model.

The next step involves unemployment and the population at risk is unemployed, longterm sick or working and those with the temporary status. The steps undertaken are the same as for disability. Thus after this step the individuals in the risk population are classified either as unemployed or as being in the temporary state. However, an important difference is that a sub-model is used to classify individuals as half- or full-time unemployed. After this follows the long-term sick and the population at risk is now long-term sick or working and those in the temporary state. Again the same procedure is used and as a result of this module, individuals now belong to the status long-term sick or temporary. The final binary model concerns old age pension; the population at risk is old age pensioner, other or working and those with temporary status age 61-70. An individual younger than 61 is not eligible for old age pension and all individuals above the age of 70 are by default old age pensioners. Again after this step individuals are classified as old age pensioners or are in the temporary state.

After these binary models a simple imputation follows, where all individuals with the temporary status who before the reform belonged to one of the binary states, i.e. individuals who have exited one of the binary states without entering another, are imputed as entering the working state and are given a number of yearly working hours equaling 1800 . This concludes the first part of the model where the binary models are used. Next we will explain the imputation of working hours and social assistance.

Every individual in the risk population (status other or working) are considered as working or voluntarily non-working. Thus, this is the typical risk population in traditional labour supply studies. For every individual in this population the tax/benefit module is called upon repeatedly in order to evaluate the budget set. For individuals classified as singles this requires 14 calls ( 7 working classes with and without social assistance) and for couples the 
creation of the budget set requires 98 calls $\left(7^{*} 7 * 2\right)^{6}$. Note that for the couples at least one of the spouses should belong to the population at risk. Given the budget set and all other variables included in the labour supply models, working hours as well as the probability of social assistance are predicted. The stochastic experiment for those models involves draws from an extreme value distribution. Also, note that different models have been estimated depending on the family type.

At this stage of the simulation, every individual has a predicted status, predicted working hours and predicted welfare participation. After this the next step in the simulation is to use the estimated elasticities from the wage equation in order to simulate the wage responses. The population at risk comprises all individuals with positive hours of work before and after the reform. In these simulations the virtual income elasticity is set to zero and the only influence comes from the net-of-tax rate. The argument for this is that the virtual income gives a valid approximation only if the budget set is convex. The data used for estimation fulfilled approximately the convexity requirement, but this is not the case in the simulation. The reason for this is that the estimation was based only on the tax system, and this produces approximately a convex budget set. Once the benefit rules are incorporated in the calculation of the budget set this can produce non-convexities.

A final step is to call the tax/benefit module again to get the predicted disposable income, calculated at the predicted values of working hours, social assistance and wages. Thus, this is the predicted disposable income for the individuals/households resulting from the tax/benefit rules. By changing these rules and repeating the simulation, disposable income before and after a reform can be compared.

Obviously, the results of the simulations are dependent on the econometric models and as mentioned above four econometric models are used to simulate the probability of disability, unemployment, long-term sickness and old age pension, and for the conditional labour supply different discrete choice models have been estimated for each family type. All of the binary models have been estimated as dynamic random-effects logit models. The data used for the estimation is a balanced LINDA panel from 2000-2006. The method used for the conditional labour supply models follows previous work by Van Soest (1995); the household model is described in Flood et al. (2004) and the model for the single-headed household in Flood et al. (2007). These models belong to the class of discrete choice model, and an advantage of this approach is that it allows us to include as many details regarding the budget

\footnotetext{
${ }^{6}$ Of course in practice the tax/benefit module is evaluated 7 times for single and 49 times for spouses, and disposable income with and without social assistance is calculated each time.
} 
set as needed and that it extends naturally into a household model, where husbands and wives jointly determine their labour supply. ${ }^{7}$

\section{Tax reform evaluation}

In this section the model introduced above, SWEtaxben, extended by the hourly wage model, is used in order to evaluate a hypothetical tax reform. In recent years the Swedish Government has decreased taxes on earnings by introducing an earned income tax credit. The credit implies lower tax rates at lower incomes whereas for a median or high income the marginal tax rate is high. For the income year 2010 there is a 20 percent central governmental tax on labour income in the income range 32 000-45 400 SEK per month and 25 percent on higher incomes. This high level of the central governmental tax on top of a proportional municipal tax - on average across all municipals of 31.7 percent - implies a highest marginal tax rate of 56.7 percent. This is one of the highest top rates of all OECD countries.

The tax change that we evaluate is in agreement with OECD recommendations and suggests a decrease in the central governmental tax. The tax is decreased by increasing the lower breakpoint (20\%) from a yearly taxable income of 372100 SEK to 480000 SEK and the upper breakpoint (25\%) from 532800 SEK to 720000 SEK. This reduces the number of taxpayers who pay the central governmental tax from 20 percent to about 10 percent.

The results are presented in Table 7. According to the first-round effects - no behavioural changes - tax revenues decrease by about 14.5 billion SEK. Included in this calculation is an expected increase in VAT as a result of an increase in disposable income. The second-round effect includes changes both in working hours and in hourly wages. First, including the effects on working hours improves the governmental budget by 8.4 billion SEK compared to the static evaluation. This effect is due to higher earnings caused by increased working hours, mainly due to an increase on the intensive margin. The increase in labour income results in increased tax revenues ( 3.6 billion) and payroll taxes (3.5 billion).

Disposable income increases by 7.3 billion and this reduces transfer payments but also increases VAT (1.3 billion). Finally, the effects on effort or hourly wages results in a further improvement of the governmental budget by 2.9 billion. Again, this is due to increased labour income (3.4 billion), payroll taxes (1.1) and VAT (0.3).

\footnotetext{
${ }^{7}$ For a detailed presentation of all models including the estimated parameters, see Ericson, Flood and Wahlberg (2009).
} 
The total effect of this 17.6 billion SEK tax cut on the central governmental budget is a deficit of 3.3 billion SEK. Thus, there are strong dynamic effects and the implied degree of self-financing is 78 percent. Of this, 58 percentage points comes from changes in working hours and 20 from changes in effort.

(Table 7 about here)

\section{Final discussion}

Studies based on a broader measure of income like taxable income suggests that taxes has larger incentive effects compared to studies based on hours of work. Saez et. al (2009) clearly illustrate the importance of the size of elasticities on the design of the tax profile at higher income. Abstracting from the income effect the tax rate which maximizes revenues depends on taxable income elasticity (e) and the income distribution. The optimal tax is given by $1 /\left(1+a^{*} e\right)$, where a is called the Pareto coefficient. This coefficient shows the income distribution at the top. ${ }^{8}$ According to Aaberge and Atkinsson (2008) the Pareto coefficient in Sweden (year 2005) is about two. This together with an assumed elasticity of 0,2 means that a highest marginal tax rate of 71 percent is optimal. As a comparison consider the highest marginal tax rate on earnings (municipal plus central government) at 56,7 percent, a payroll tax at 31,42 percent and an average VAT at 17,6 percent, this sum to 73 percent, which is in line with the optimal rate. However this is given an elasticity of 0,2 , if instead a value of 0,4 is assumed this implies an optimal tax of only 56 percent. Since this illustration is related to high income earners even an elasticity of 0,4 is not considered high relative to the findings in the international literature.

This simple illustration shows the importance of the size of the economic incentives in the design of the tax profiles. Obviously this highlights the importance of the precision in the estimated elasticities. As been discussed above the hourly wage elasticities estimated in our paper are relatively small compared to other studies. Several reasons for these results have been mentioned but it also raises an important issue discussed in Chetty (2009). His argument is that individuals do not change their behaviour due to small changes. The cost of adjustment is too high; Chetty use the term friction for this inertia or lack of response. Friction is a reasonable explanation for the often small reported elasticities in studies using data after the

\footnotetext{
${ }^{8}$ The size of the Pareto coefficient depends on the share of the top percent of the top decile. For details see Atkinson (2004). A large coefficient implies a more equal distribution.
} 
1991 tax reform data. The tax changes after 1991 can be described by many small adjustments. The first major tax change was introduced in 2007, the earned income tax credit. However, this reform has been criticized for its complicated design and it has been argued that many individuals lack knowledge of it. ${ }^{9}$ This raises the importance issue of tax designs our understanding is that in order for a tax reform to have expected behavioural effects it should imply a substantial change but also a simple design.

The simple illustration of an optimal tax rate together with the evaluation based on an advanced microsimulation model shows that even small elasticities can generate substantial dynamic effects. An important ambition in the development of SWEtaxben has been to minimize the risk of exaggerated behavioral effects. It can be argued that these effects probably are biased downward, both with respect to the labor supply effects as well as on hourly wages. If our estimates can be regarded as a lower limit and at the same time imply considerable dynamic effects, this is a strong argument for the need to consider behavioral effects in the design of the tax/benefit systems. Still, it is important to recognize the fact that, as usual, the elasticities are estimated with some uncertainty or lack of precision. The sensitivity analyses in this study illustrates that estimated elasticities are not unaffected by differences in data selection, estimation method and choice of instruments. This sensitivity together with the "the curse of precision" - small differences in estimated elasticities have large effects on the aggregated results such as tax revenues, hours of work and income offers a great challenge in policy analysis.

As far as we know SWEtaxben is the only microsimulation model that considers behavioral effects both in the hour and effort dimension. However, this generalization has been obtained under some unrealistic assumptions and simplifications. The labor supply model assumes that hourly wages are exogenous (independent of working hours) whereas in the hourly wage model this assumption is dropped. In principle, this inconsistency could be addressed by a model that consider the joint choice of hours and wage. One such framework is given in Aaberge et. al. (1995). The most important characteristic of this approach is that hourly wages and demand side restrictions are integrated with the choice of working hours. In this approach there is a potential for considering the joint effect of a tax change on wages and hours.

A critique against the method used in this study as well as in Aaberge et. al is that they are based on structural models - models derived from an underlying utility function - and

\footnotetext{
${ }^{9}$ See Anderson \& Antelius (2010)
} 
therefor sensitive towards the underlying assumptions. For this reason the focus recently has shifted towards evaluation based on the idea of a "natural experiment". The advantage of this approach is robustness. However, a problem is that tax reforms quite often are far from the requirement needed for a natural experiment. If the reform is general and applicable for all tax payers then the distinction between treatment- and control group is difficult and this creates severe identification problems. For evaluations of general as well as hypothetical reforms the need of structural models seems obvious. However, an important task for future research is to use the insight from the "natural experiment" literature in order to validate structural models. Given that the structural model approach can be verified by less demanding natural experimental results increase the usefulness for micro simulation with behavioral responses as a useful tool for policy evaluation. 


\section{References}

Aaberge, Rolf, John K. Dagsvik and Steinar Strøm. (1995). "Labor Supply Responses and Welfare Effects of Tax Reforms", Scandinavian Journal of Economics 97(4): 635-659.

Aaberge, R. and Atkinson, B.A (2008). "Top incomes in Norway", Statistics Norway, research paper no. 552

Andersson, C and J. Antelius (2010). "Jobbskatteavdraget - bra tänkt men illa känt", Ekonomisk Debatt, 2010:2

Atkinson, A.B. (2004). "Income tax and top incomes over the twentieth century", Hacienda Pública Española, Revista de Economía Pública, 168: 123-141.

Blomquist, S. and H. Selin (2008) "Hourly Wage Rate and Taxable Labor Income Responsiveness to Changes in Marginal tax Rates", Working Paper 2008:16, Department of Economics, Uppsala University.

Blow, L. and I. Preston (2002) "Deadweight Loss and Taxation of Earned Income: Evidence from Tax Records of the UK Self Employed" Institute for Fiscal Studies Working Paper WP02/15

Carlin, P.S and Flood, L.R., 1997, "Do children Affect the Labor Supply of Swedish men?". Labour Economics, Volume 4, issue 2, pages 167-183

Chetty, R. (2009). "Bounds on elasticities with optimization frictions: A synthesis of micro and macro evidence on labour supply”, NBER Working Paper No. 15616.

Deaton, A. (2009) ' Instruments of development: Randomization in the tropics, and the search for the elusive keys to economic development', Research Program in Development Studies, Center for Health and Wellbeing, Princeton University

Edin, P. A. and Fredriksson, P. (2000), LINDA - Longitudinal Individual DAta for Sweden, Working Paper 2000:19, Uppsala Universitet, Nationalekonomiska institutionen.

Ericson, P., Flood, L.R. and Wahlberg, R. (2009). SWEtaxben: A Swedish Tax/benefit Micro Simulation Model and an Evaluation of a Swedish Tax Reform, Working paper No 346 in SWOPEC, http://swopec.hhs.se/gunwpe/abs/gunwpe0346.htm

Feldstein, M. (1995) 'The Effect of Marginal Tax Rates on Taxable Income: A Panel Study of the 1986 Tax Reform', Journal of Political Economy, Vol. 103, No. 3, 551-572

Feldstein, M. (1999) 'Tax Avoidance and the Deadweight loss of the Income Tax', Review of Economics and Statistics 81(4), 674-80

Flood, L.R. 1990, Att mäta och estimera utbudet av arbetskraft, I Tid och Råd, IUI of University of Gothenburg 
Flood, L., J. Hansen, and R. Wahlberg. (2004). Household Labor Supply and Welfare Participation in Sweden. Journal of Human Resources, 39(4): 1008 -1032.

Flood, L., R. Wahlberg, and E. Pylkänen. (2007), From Welfare to Work: Evaluating a Proposed Tax and Benefit Reform Targeted at Single Mothers in Sweden. LABOUR, 21(3): 443-471.

Gelber, A.M. (2008) 'Taxation and family labor supply', Job market paper, Harvard University.

Goolsbee, A. (2000). "It's not about the money: Why natural experiments don't work on the rich' in Does Atlas shrug? The economic consequences of taxing the rich”, J. Slemrod (Ed.). Harvard, Russell Sage Foundation.

Gruber, J. and E. Saez (2002) 'The elasticity of taxable income: Evidence and implications', Journal of Public Economics 84, 1-32.

Hansson, Å (2006). "Svensk skattepolitik: Från Pomperipossa via århundradets skattereform till värnskattens utdragna avskaffande." The Swedish model, RATIO, rapport 3.

Hansson, $\AA$. (2007) 'Taxpayers responsiveness to tax rate changes and implications for the cost of taxation', International Tax and Public Finance 14(5), 563-82.

Holmlund, B. and M. Söderström (2008) 'Hur påverkas inkomsterna av skatteförändringar' IFAU Working paper 2008:28

Imbens, G.W. and M. Wooldridge (2009) 'Recent Developments in the Econometrics of Program Evaluation', Journal of Economic Literature, 47:1, p. 5-86.

Klevmarken , N.A, (2000) 'Did the Tax Cuts Increase Hours of Work? A Statistical Analysis of a Natural Experiment. KYKLOS, 53, 337-362.

Ljunge, M. and K. Ragan (2006) 'Labor supply and the tax reform of the century?', University of Chicago, mimeo.

MaCurdy, T, D, Green and H, Paarsch (1990) `Assessing Empirical Approaches for analyzing Taxes and Labor Supply', Journal of Human Resources, 25(3): 415-90.

Meghir, C. and D. Phillips (2009) 'Labour Supply and Taxes', Report of a Commission on Reforming the Tax System for the 21st Century, Chaired by Sir James Mirrlees www.ifs.org.uk/mirrleesreview.

Saez, E, J, Slemrod and S.H, Giertz (2009) 'The Elasticity of Taxable Income with respect to Marginal Tax Rates : A Critical Review', Working Paper 15012, http://www.nber.org/papers/w15012

Selén, J. (1995) 'Measurement errors in hourly earnings', Paper presented at the conference on methodological issues in official statistics, statistics Sweden.

Selén, J. (2005) 'Taxable income responses to tax changes: Panel analyses of Swedish 
reforms', Mimeo, Trade Union Institute for Economic Research.

Sillamaa and Veall (2001) 'The effect of marginal tax rates on taxable income: A panel study of the 1988 tax flattening in Canada', Journal of Public Economics 80(3), 341-56.

Tax Statistical Yearbook of Sweden (2007)

Wooldridge, J.M. (2002) Econometric analysis of cross section and panel data, Cambridge and London: MIT Press.

Van Soest, A. (1995), Structural Models of Family Labor Supply, Journal of Human Resources 30(1), 63-88. 
Figure 1 Distribution in working hours in 2007, by gender
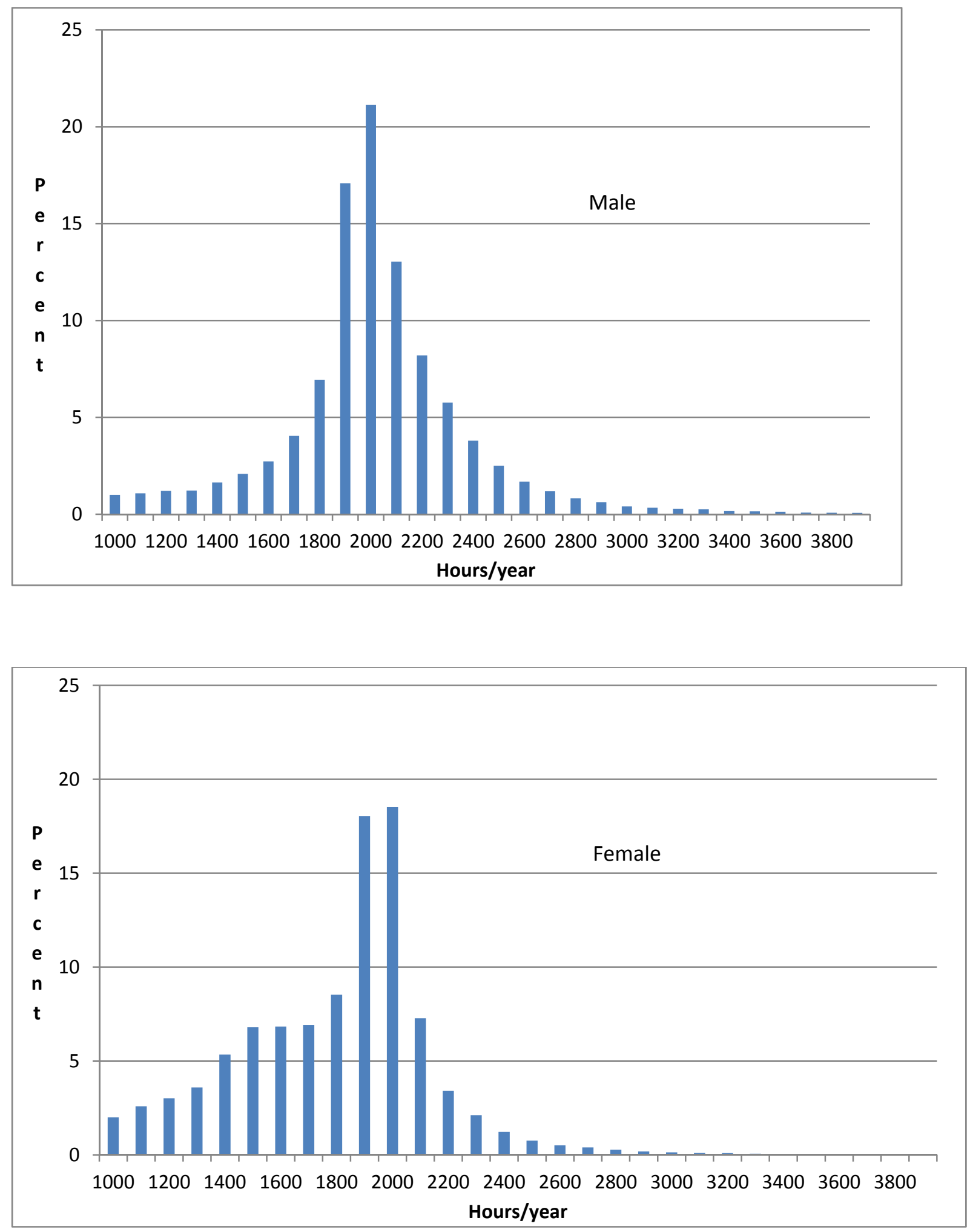
Figure 2. Wage distribution in 2007 by gender
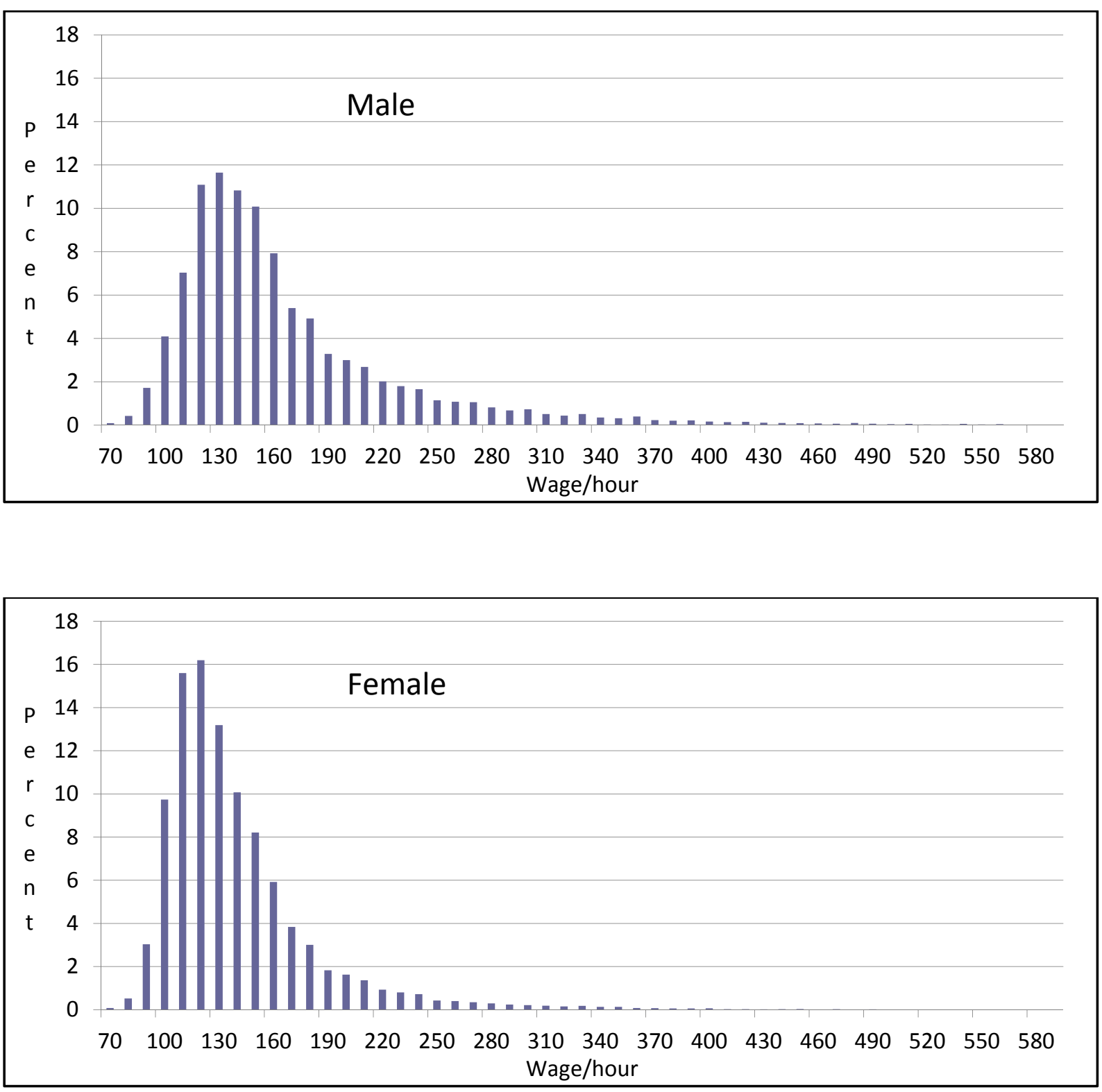
Figure 3. Changes in real wages, working hours and marginal taxes 1992-2007

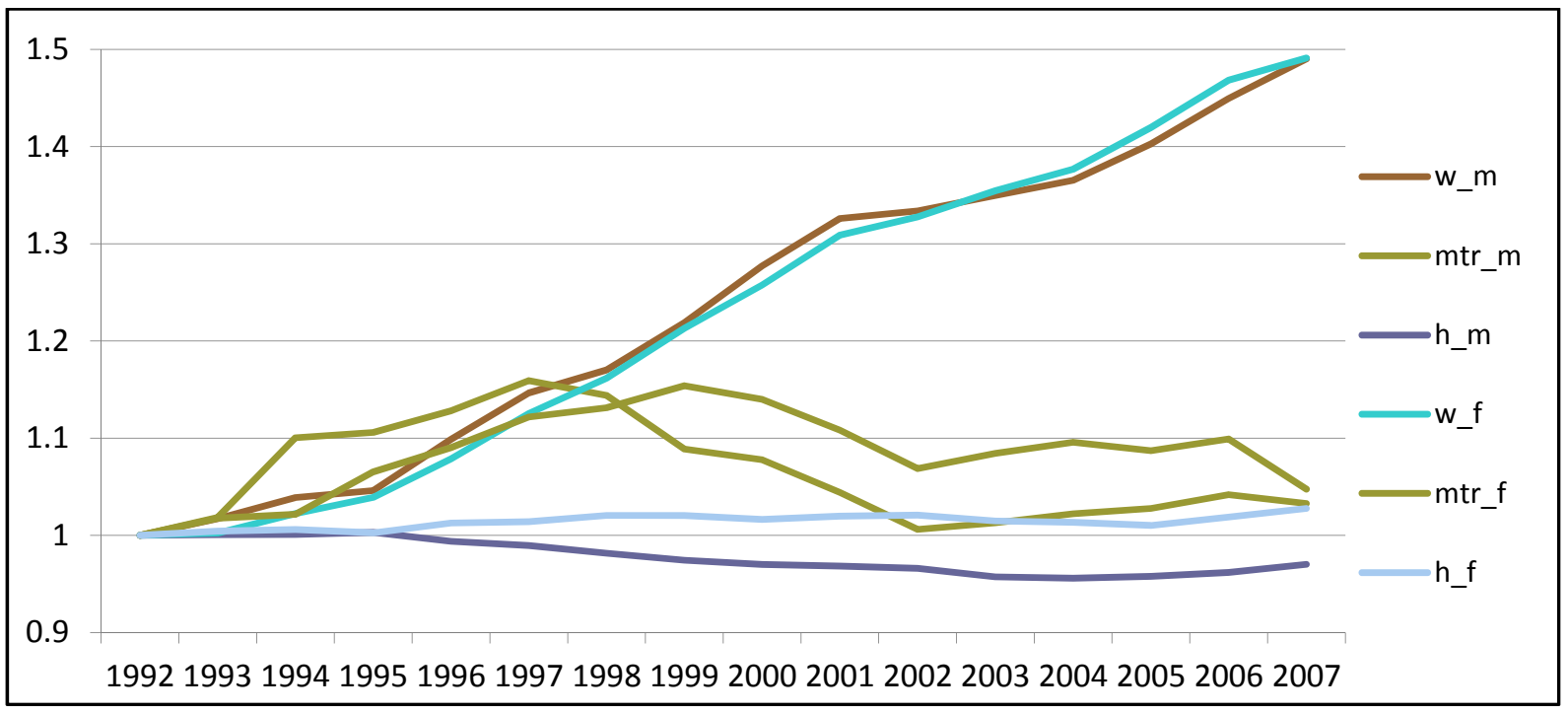

Figure 4. Change in wage distribution 1992-2007

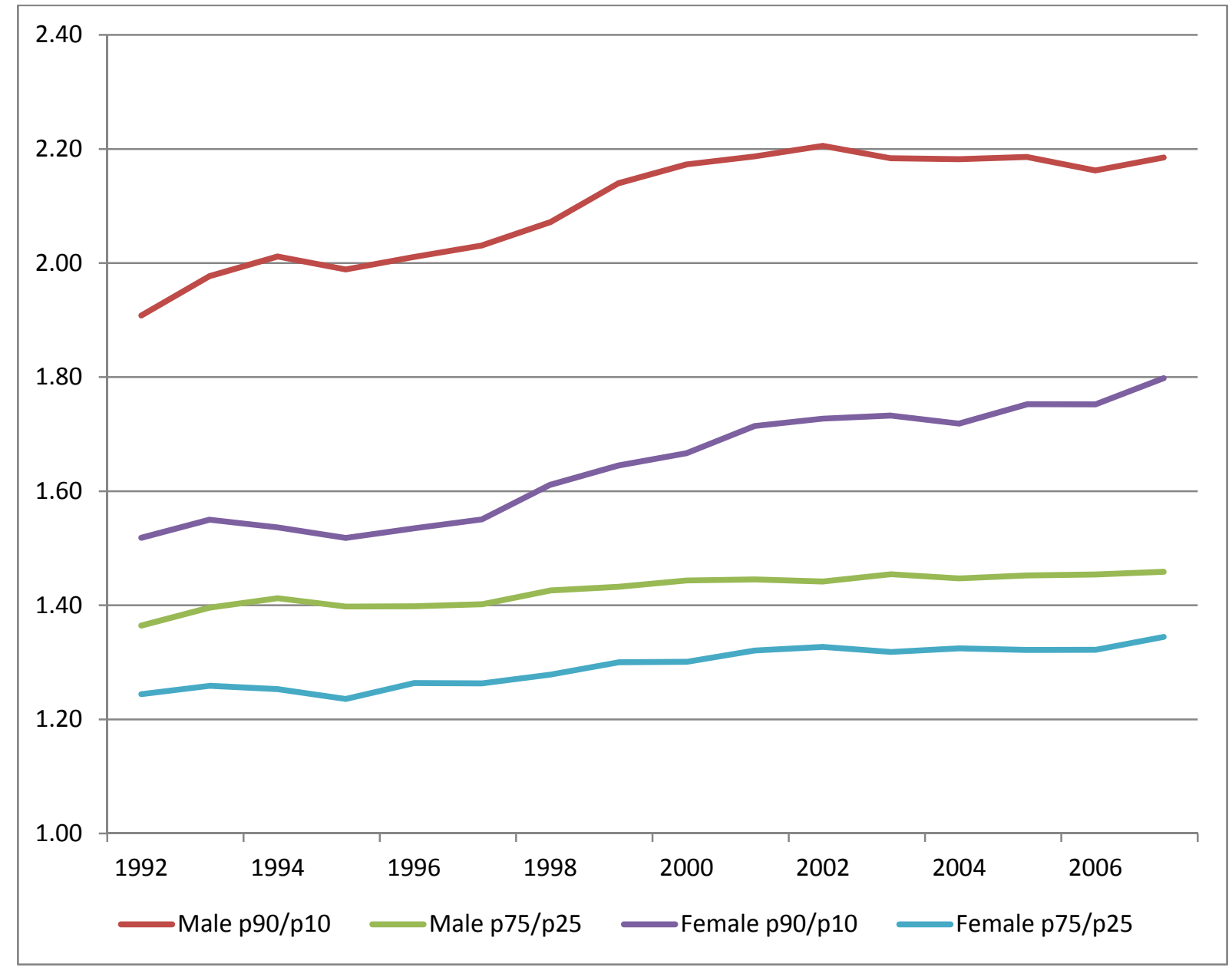


Figure 5. Hourly wage rate and working hours.

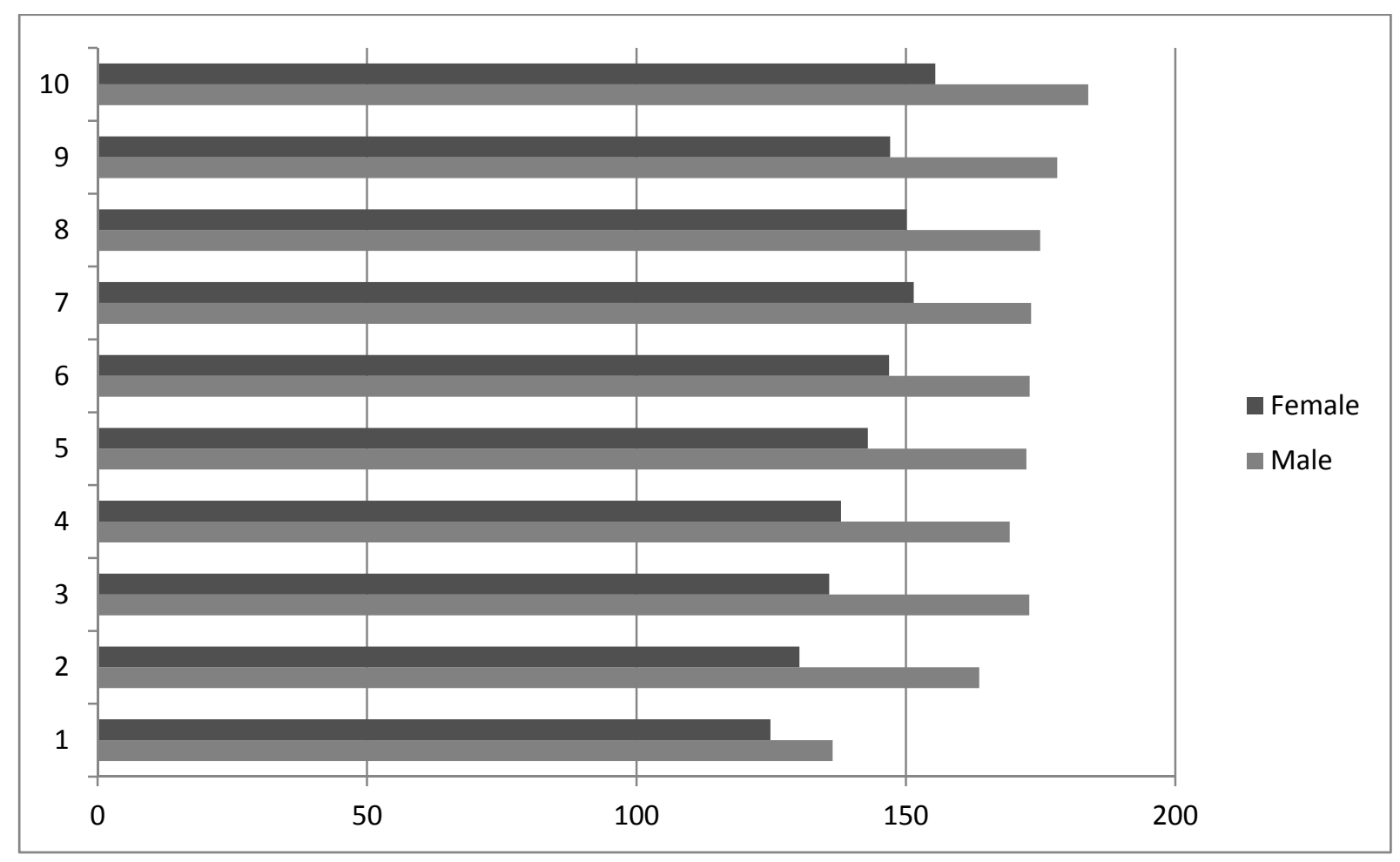


Figure 6. Structure of SWEtaxben.

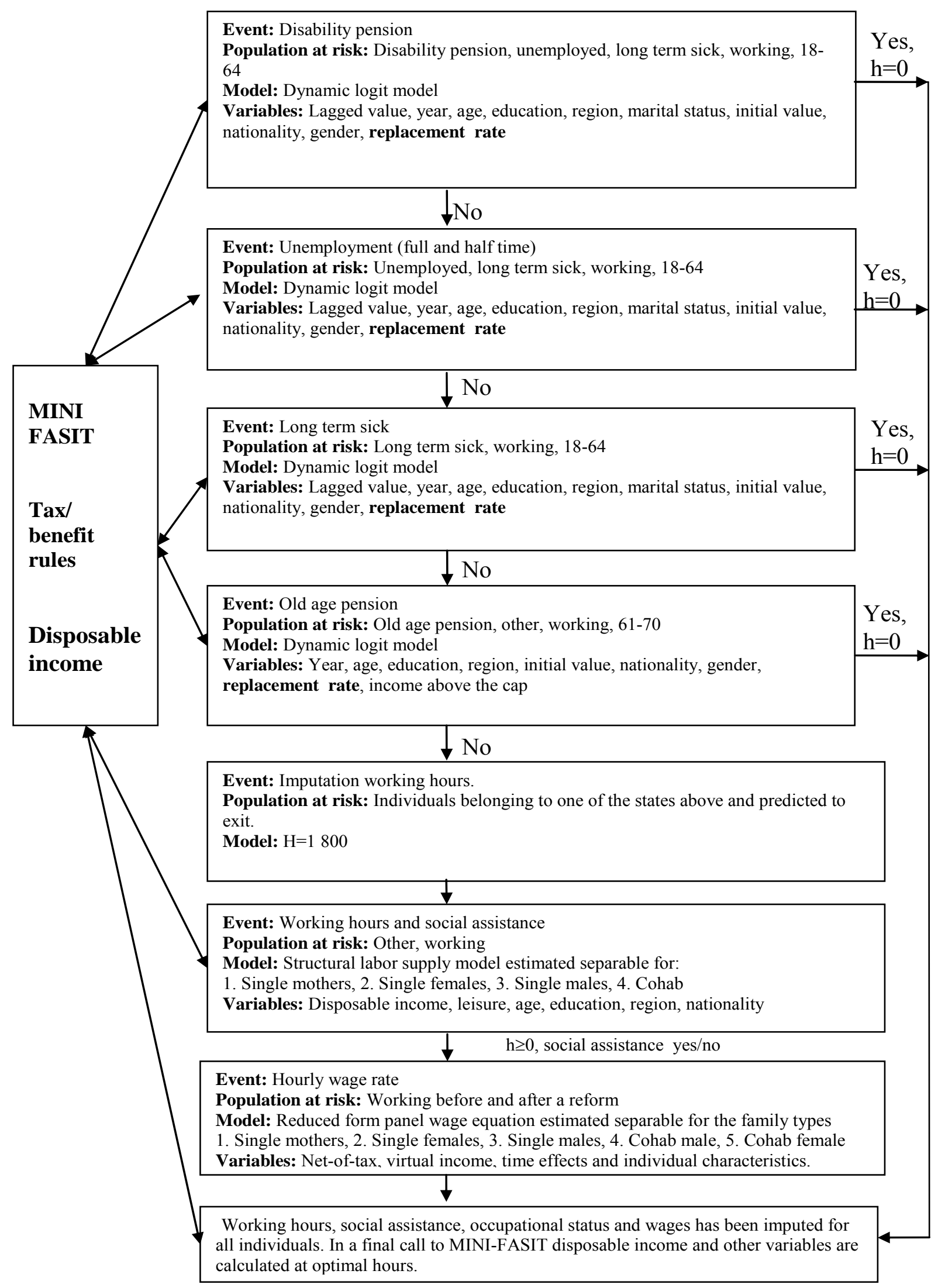


Table 1: Taxable and Total Income Elasticities (Subsample from Meghir \& Phillips (2008))

\begin{tabular}{|c|c|c|c|c|c|c|}
\hline Author (Date) & Data (Years) & Tax Change & Sample & $\begin{array}{c}\text { Controls for Income } \\
\text { Distribution and Mean } \\
\text { Reversion }\end{array}$ & Definition of Income & Elasticity Results \\
\hline $\begin{array}{l}\text { Feldstein } \\
\text { (1995) }\end{array}$ & $\begin{array}{l}\text { NBER Tax Panel } 1985 \\
\& 1988\end{array}$ & TRA 86 & $\begin{array}{l}\text { Married, non-aged non-S } \\
\text { corp Income }>\$ 30 \mathrm{k}\end{array}$ & None & AGI Taxable Income & $\begin{array}{l}0.75-1.31 .1 \text { ('lower } \\
\text { income') to } 3.05 \text { ('higher } \\
\text { income') }\end{array}$ \\
\hline $\begin{array}{l}\text { Sillamaa \& } \\
\text { Veall } \\
(2000)\end{array}$ & $\begin{array}{l}\text { Canadian Longitudinal } \\
\text { Admin Survey. } \\
1986 \text { to } 1989\end{array}$ & $\begin{array}{c}\text { Canadian } \\
\text { TRA } 88\end{array}$ & $\begin{array}{l}\text { Federal Tax paid }>\$ 625 \\
\text { (Can) } \\
\text { Aged } 25-6465+\end{array}$ & $\begin{array}{l}\text { Include log income in base } \\
\text { year. Instrumental Variables } \\
\text { approach }\end{array}$ & $\begin{array}{c}\text { Gross Income } \\
\text { Taxable Income } \\
\text { Employment Income S/E } \\
\text { Income } \\
\text { High-Income GI }\end{array}$ & $\begin{array}{l}0.25 \\
0.14 \\
0.22 \\
1.12 \\
1.30\end{array}$ \\
\hline $\begin{array}{l}\text { Goolsbee et al } \\
(2000)\end{array}$ & $\begin{array}{l}\text { Tax Statistics (agg) } \\
1922-1989\end{array}$ & $\begin{array}{l}\text { Various } \\
\text { Reforms }\end{array}$ & Income $>\$ 30 \mathrm{k}$ & None & Taxable Income & $\begin{array}{l}-1.3 \text { to } 2 \text { depending on the } \\
\text { reform }\end{array}$ \\
\hline $\begin{array}{c}\text { Gruber \& Saez } \\
\quad(2002)\end{array}$ & $\begin{array}{l}\text { NBER Tax Panel } 1979 \\
\text { to } 1990\end{array}$ & $\begin{array}{l}\text { ERTA } 81 \& \\
\text { TRA } 86 \\
\end{array}$ & \begin{tabular}{|l|} 
Same marital status in \\
paired-years
\end{tabular} & $\begin{array}{l}\text { Include Log Income, trend } \\
\text { effects and a } 10 \text { piece spline. }\end{array}$ & $\begin{array}{l}\text { 'Broad Income' Taxable } \\
\text { Income }\end{array}$ & $\begin{array}{c}0.120 .40 .57 \text { (high income) } \\
0.18 \text { (low income) } \\
\end{array}$ \\
\hline \multicolumn{7}{|c|}{$\begin{array}{l}\text { ERTA 81: Economic Recovery Tax Act (1981), TRA 86: Tax Reform Act (1986), (A)GI: (Adjusted) Gross Income. NBER: National Bureau of Economic Research. IRS: Internal Revenue } \\
\text { Service. }\end{array}$} \\
\hline
\end{tabular}


Table 2: Taxable and Total Income Elasticities based on Swedish data

\begin{tabular}{|c|c|c|c|c|c|c|}
\hline $\begin{array}{l}\text { Author } \\
\text { (Date) }\end{array}$ & Data (Years) & $\begin{array}{c}\text { Tax } \\
\text { Change }\end{array}$ & Sample & $\begin{array}{c}\text { Controls for Income } \\
\text { Distribution and Mean } \\
\text { Reversion }\end{array}$ & $\begin{array}{l}\text { Definition of } \\
\text { Income }\end{array}$ & Elasticity Results \\
\hline Selén 2002 & $\begin{array}{c}\text { HINK } \\
1989 \& 1992\end{array}$ & 1991 & Men age $25-55$ & $\begin{array}{c}\text { Include log taxable income in } \\
\text { base year. Diff-in-diff and the } \\
\text { instrumental Variables } \\
\text { approach }\end{array}$ & $\begin{array}{c}\text { Taxable income } \\
\text { and other income } \\
\text { concepts }\end{array}$ & $0.2-04$ \\
\hline $\begin{array}{c}\text { Ljunge \& } \\
\text { Ragan (2006) }\end{array}$ & $\begin{array}{c}\text { LINDA } \\
1989 \text { to } 1994\end{array}$ & 1991 & $\begin{array}{c}\text { Earned income SEK } \\
>60,000, \text { Transfer income }< \\
50,000 \\
\text { Age } 25-55\end{array}$ & $\begin{array}{l}\text { Include log income in base } \\
\text { year. Instrumental Variables } \\
\text { approach }\end{array}$ & Earned income & 0.35 \\
\hline $\begin{array}{l}\text { Hansson } \\
(2007)\end{array}$ & $\begin{array}{c}\text { LINDA } \\
1989 \& 1992\end{array}$ & 1991 & $\begin{array}{c}\text { Taxable income }>01989 \& \\
1992 \\
\text { Unchanged marital status and } \\
\text { family size } \\
\text { Age 25-60 }\end{array}$ & $\begin{array}{l}\text { Include log taxable earning in } \\
\text { base year. Diff-in-diff and the } \\
\text { instrumental Variables } \\
\text { approach }\end{array}$ & $\begin{array}{l}\text { Taxable earned } \\
\text { income }\end{array}$ & $0.4-0.5$ \\
\hline $\begin{array}{l}\text { Gelber } \\
(2008)\end{array}$ & $\begin{array}{c}\text { LINDA } \\
\text { 1988-1991 }\end{array}$ & 1991 & $\begin{array}{l}\text { Married couples } \\
\text { age } 18-65 \\
\text { Earned income in base } \\
\text { year }>0 \\
\text { No self employed }\end{array}$ & $\begin{array}{l}\text { Include log taxable earning in } \\
\text { base year. First difference and } \\
\text { the instrumental Variables } \\
\text { approach }\end{array}$ & $\begin{array}{l}\text { Earned income } \\
\text { Compensated } \\
\text { husband } \\
\text { wife }\end{array}$ & $\begin{array}{l}0.25 \\
0.49\end{array}$ \\
\hline $\begin{array}{l}\text { Holmlund \& } \\
\text { Söderström } \\
(2008) \\
\end{array}$ & $\begin{array}{c}\text { LINDA } \\
1991-2002\end{array}$ & 1991-2002 & $\begin{array}{l}\text { Taxable income above } \\
\text { median base year } \\
\text { Age 20-59 }\end{array}$ & $\begin{array}{l}\text { Instruments based on two year } \\
\text { lagged income. }\end{array}$ & $\begin{array}{c}\text { Taxable income } \\
\text { Men } \\
\text { Women } \\
\end{array}$ & $\begin{array}{c}\text { Short: } 0.2 \text { Long: } 0.1 \\
\text { Short:-0.1 Long:0 }\end{array}$ \\
\hline $\begin{array}{l}\text { Blomquist \& } \\
\text { Selin } \\
(2008)\end{array}$ & $\begin{array}{c}\text { LNU } \\
1981 \& 1991\end{array}$ & 1981-1991 & $\begin{array}{l}\text { Married couples } \\
\text { No selfemployed } \\
\text { Aged 22-54 }\end{array}$ & $\begin{array}{l}\text { Lagged taxable income } \\
\text { Spline in lagged income } \\
\text { Instruments based on } \\
\text { predicted taxable income } \\
\text { (including TI in the middle } \\
\text { year.) }\end{array}$ & $\begin{array}{c}\text { Taxable income } \\
\text { Men } \\
\text { Women } \\
\text { Hourly wage } \\
\text { Men } \\
\text { Women } \\
\end{array}$ & $\begin{array}{c}0.2-0.25 \\
0.9-1.4 \\
0.14-0.16 \\
0.4-0.6 \\
\end{array}$ \\
\hline
\end{tabular}


Table 3. Hourly wages, marginal taxes and working hours

\begin{tabular}{|c|c|c|c|c|c|c|}
\hline \multirow[t]{2}{*}{ Year } & \multicolumn{3}{|c|}{ Male } & \multicolumn{3}{|c|}{ Female } \\
\hline & Hourly wage & Marginal tax & Yearly hours & Hourly wage & Marginal tax & Yearly hours \\
\hline 1992 & 119 & 41.29 & 2152 & 99 & 34.84 & 1811 \\
\hline 1993 & 121 & 42.05 & 2153 & 99 & 35.44 & 1819 \\
\hline 1994 & 124 & 45.44 & 2154 & 101 & 35.59 & 1822 \\
\hline 1995 & 125 & 45.67 & 2158 & 102 & 37.11 & 1816 \\
\hline 1996 & 131 & 46.58 & 2139 & 106 & 37.98 & 1834 \\
\hline 1997 & 136 & 47.86 & 2129 & 111 & 39.08 & 1837 \\
\hline 1998 & 139 & 47.24 & 2112 & 115 & 39.41 & 1849 \\
\hline 1999 & 145 & 44.96 & 2096 & 120 & 40.20 & 1848 \\
\hline 2000 & 152 & 44.51 & 2087 & 124 & 39.71 & 1841 \\
\hline 2001 & 158 & 43.12 & 2084 & 129 & 38.61 & 1847 \\
\hline 2002 & 159 & 41.54 & 2078 & 131 & 37.23 & 1849 \\
\hline 2003 & 161 & 41.82 & 2060 & 134 & 37.77 & 1838 \\
\hline 2004 & 162 & 42.21 & 2056 & 136 & 38.17 & 1835 \\
\hline 2005 & 167 & 42.43 & 2061 & 140 & 37.87 & 1830 \\
\hline 2006 & 173 & 43.02 & 2069 & 145 & 38.29 & 1845 \\
\hline 2007 & 177 & 42.65 & 2087 & 147 & 36.49 & 1862 \\
\hline
\end{tabular}


Table 4. Estimated hourly wage parameters

\begin{tabular}{|c|c|c|c|c|c|c|c|c|c|c|}
\hline & & & \multirow{2}{*}{$\begin{array}{l}\text { Single } \\
\text { female }\end{array}$} & \multirow[b]{3}{*}{ Robust } & \multirow{3}{*}{ male } & \multirow[b]{3}{*}{ Robust } & \multicolumn{2}{|c|}{ Married Cohab } & \multirow{3}{*}{ Male } & \multirow[b]{3}{*}{ Robust } \\
\hline & \multicolumn{2}{|c|}{ Single Mother } & & & & & Female & & & \\
\hline & & Robust & & & & & & Robust & & \\
\hline Iw & Coef. & Std. Err. & Coef. & Std. Err. & Coef. & Std. Err. & Coef. & Std. Err. & Coef. & Std. Err. \\
\hline Net-of-tax & 0928 & 0.0104 & 0.1409 & 0.0056 & 0.1589 & 0.0051 & 0.0097 & 0.0031 & 0.0502 & 0.0034 \\
\hline Virtual & 0.0245 & 0.0014 & 0.0267 & 0.0006 & 0.0376 & 0.0006 & 0.0201 & 0.0010 & 0.0578 & 0.0016 \\
\hline 1994 & 0.0313 & 0.0037 & 0.0277 & 0.0022 & 0.0243 & 0.0031 & 0.0218 & 0.0012 & 0.0102 & 0.0020 \\
\hline 1995 & 0.0513 & 0.0056 & 0.0400 & 0.0035 & 0.0272 & 0.0049 & 0.0414 & 0.0019 & 0.0222 & 0.0031 \\
\hline 1996 & 0.0956 & 0.0079 & 0.0789 & 0.0048 & 0.0776 & 0.0068 & 0.0819 & 0.0026 & 0.0653 & 0.0043 \\
\hline 1997 & 0.1458 & 0.0102 & 0.1210 & 0.0061 & 0.1138 & 0.0088 & 0.1275 & 0.0033 & 0.1020 & 0.0055 \\
\hline 1998 & 0.1788 & 0.0125 & 0.1577 & 0.0075 & 0.1422 & 0.0107 & 0.1634 & 0.0040 & 0.1305 & 0.0067 \\
\hline 1999 & 0.2289 & 0.0146 & 0.2011 & 0.0089 & 0.1709 & 0.0127 & 0.2114 & 0.0048 & 0.1638 & 0.0080 \\
\hline 2000 & 0.2715 & 0.0168 & 0.2433 & 0.0102 & 0.2156 & 0.0146 & 0.2513 & 0.0055 & 0.2018 & 0.0092 \\
\hline 2001 & 0.3179 & 0.0191 & 0.2844 & 0.0116 & 0.2499 & 0.0165 & 0.2957 & 0.0062 & 0.2318 & 0.0104 \\
\hline 2002 & 0.3413 & 0.0213 & 0.3005 & 0.0129 & 0.2512 & 0.0184 & 0.3185 & 0.0069 & 0.2391 & 0.0116 \\
\hline 2003 & 3707 & 0.0235 & 0.3241 & 0.0142 & 0.2625 & 0.0203 & 0.3453 & 0.0077 & 0.2508 & 0.0128 \\
\hline 2004 & 4009 & 0.0258 & 0.3419 & 0156 & 0.2734 & 0.0222 & 0.3671 & 0.0084 & 0.2610 & 0.0140 \\
\hline 2005 & 0.4361 & 0.0280 & 0.3710 & 0.0169 & 0.2920 & 0.0242 & 0.4012 & 0.0091 & 0.2816 & 0.0152 \\
\hline 2006 & 0.4762 & 0.0303 & 0.4038 & 0.0183 & 0.3186 & 0.0261 & 0.4351 & 0.0098 & 0.3058 & 0.0164 \\
\hline 2007 & 0.4919 & 0.0324 & 0.4122 & 0.0196 & 0.3270 & 0.0281 & 0.4510 & 0.0106 & 0.3176 & 0.0176 \\
\hline age & 0100 & 0.0032 & 0.0284 & 0.0016 & 0.0416 & 0.0021 & 0.0122 & 0.0009 & 0.0364 & 0.0015 \\
\hline age 2 & -0.0210 & 0.0027 & -0.0348 & 0008 & -0.0454 & 0.0008 & -0.0211 & 0.0006 & -0.0366 & 0.0008 \\
\hline Gymnasiuı & 0021 & 0.0302 & -0.0061 & 0.0195 & -0.0110 & 0.0167 & 0.0108 & 0.0117 & -0.0408 & 0.0166 \\
\hline University & -0.2830 & 0.0388 & -0.1388 & 0.0208 & -0.2824 & 0.0193 & -0.2422 & 0.0142 & -0.3082 & 0.0204 \\
\hline age*gymn: & 0.0000 & 0.0008 & 0.0000 & 0.0004 & 0.0004 & 0.0004 & -0.0001 & 0.0002 & 0.0012 & 0.0003 \\
\hline Age*unive & 0.0083 & 0.0009 & 0.0055 & 0.0004 & 0.0098 & 0.0005 & 0.0071 & 0.0003 & 0.0084 & 0.0003 \\
\hline Big city & 0119 & .0082 & 0.0311 & 0036 & .0273 & 0.0042 & .0066 & 0.0037 & 0.0232 & 0.0052 \\
\hline Medium ci & 0.0034 & 0.0053 & 0.0048 & 0.0028 & -0.0060 & 0.0031 & 0.0038 & 0.0023 & -0.0032 & 0.0032 \\
\hline \#children & -0.0093 & 0.0022 & & & & & 0.0011 & 0.0007 & 0.0052 & 0.0009 \\
\hline children 0 - & -0.0115 & 0.0049 & & & & & -0.0142 & 0.0014 & 0.0048 & 0.0014 \\
\hline children 3 . & -0.0038 & 0.0031 & & & & & -0.0022 & 0.0011 & 0.0045 & 0.0012 \\
\hline children 7 . & & 0.0018 & & & & & 0.0020 & 0.0008 & 0.0040 & 0.0009 \\
\hline Constant & 4.2212 & 0.0915 & 3.7833 & 0.0532 & 3.4727 & 0.0627 & 4.1713 & 0.0350 & 3.2226 & 0.0544 \\
\hline ma u & 0.2183 & & 0.1728 & & 0.2081 & & 0.2136 & & 0.2764 & \\
\hline sigma_e & 0.0780 & & 0.0819 & & 0.1021 & & 0.0782 & & 0.1019 & \\
\hline
\end{tabular}


Table 5. Estimated taxable income parameters

\begin{tabular}{|c|c|c|c|c|c|c|c|c|c|c|}
\hline & & & \multirow{2}{*}{$\begin{array}{l}\text { Single } \\
\text { female }\end{array}$} & & \multirow{3}{*}{ male } & & \multicolumn{2}{|c|}{ Married Cohab } & \multirow{3}{*}{ Male } & \multirow[b]{3}{*}{ Robust } \\
\hline & \multicolumn{2}{|c|}{ Single Mother } & & & & & Female & & & \\
\hline & & Robust & & Robust & & Robust & & Robust & & \\
\hline Iw & Coef. & Std. Err. & Coef. & Std. Err. & Coef. & Std. Err. & Coef. & Std. Err. & Coef. & Std. Err. \\
\hline Net-of-tax & 0.4192 & 0.0144 & 0.4875 & 0.0085 & 0.4396 & 0.0064 & 0.0442 & 0.0048 & 0.1153 & 0.0042 \\
\hline Virtual & 0.1119 & 0.0026 & 0.1009 & 0.0010 & 0.1018 & 0.0009 & 0.0809 & 0.0022 & 0.1447 & 0.0031 \\
\hline 1994 & 0.0350 & 0.0054 & 0.0395 & 0.0028 & 0.0363 & 0.0035 & -0.0097 & 0.0019 & -0.0049 & 0.0023 \\
\hline 1995 & 0.0010 & 0.0085 & -0.0061 & 0.0040 & 0.0128 & 0.0053 & -0.0220 & 0.0031 & -0.0063 & 0.0036 \\
\hline 1996 & 0.0394 & 0.0118 & 0.0183 & 0.0056 & 0.0356 & 0.0074 & -0.0062 & 0.0043 & 0.0087 & 0.0050 \\
\hline 1997 & 0.0574 & 0.0152 & 0.0333 & 0.0071 & 0.0501 & 0.0095 & 0.0036 & 0.0055 & 0.0215 & 0.0064 \\
\hline 1998 & 0.0626 & 0.0184 & 0.0470 & 0.0087 & 0.0561 & 0.0116 & 0.0042 & 0.0067 & 0.0188 & 0.0078 \\
\hline 1999 & 0.0798 & 0.0216 & 0.0555 & 0.0103 & 0.0461 & 0.0136 & 0.0135 & 0.0079 & 0.0182 & 0.0092 \\
\hline 2000 & 0.0718 & 0.0250 & 0.0645 & 0.0118 & 0.0625 & 0.0157 & 0.0105 & 0.0091 & 0.0263 & 0.0106 \\
\hline 2001 & 0.0837 & 0.0283 & 0.0777 & 0.0134 & 0.0726 & 0.0178 & 0.0180 & 0.0104 & 0.0319 & 0.0120 \\
\hline 2002 & 0.0667 & 0.0316 & 0.0608 & 0.0150 & 0.0469 & 0.0199 & 0.0065 & 0.0116 & 0.0154 & 0.0135 \\
\hline 2003 & 0.0700 & 0.0350 & 0.0639 & 0.0165 & 0.0330 & 0.0219 & -0.0091 & 0.0128 & 0.0027 & 0.0149 \\
\hline 2004 & 0.0704 & 0.0383 & 0.0653 & 0.0181 & 0.0259 & 0.0240 & -0.0233 & 0.0140 & -0.0038 & 0.0163 \\
\hline 2005 & 0.0625 & 0.0416 & 0.0569 & 0.0197 & 0.0169 & 0.0261 & -0.0300 & 0.0152 & -0.0033 & 0.0177 \\
\hline 2006 & 0.0671 & 0.0449 & 0.0749 & 0.0213 & 0.0282 & 0.0282 & -0.0292 & 0.0164 & -0.0057 & 0.0192 \\
\hline 2007 & 0.0379 & 0.0483 & 0.0378 & 0.0229 & 0.0015 & 0.0303 & -0.0467 & 0.0177 & -0.0169 & 0.0206 \\
\hline age & 0.0447 & 0.0045 & 0.0643 & 0.0018 & 0.0734 & 0.0023 & 0.0511 & 0.0015 & 0.0545 & 0.0017 \\
\hline age 2 & -0.0184 & 0.0035 & -0.0482 & 0.0008 & -0.0575 & 0.0008 & -0.0249 & 0.0009 & -0.0340 & 0.0009 \\
\hline Gymnasiuı & -0.0395 & 0.0427 & 0.0314 & 0.0215 & 0.0893 & 0.0187 & -0.0416 & 0.0185 & 0.0333 & 0.0180 \\
\hline University & -0.3152 & 0.0546 & -0.0675 & 0.0230 & -0.1546 & 0.0225 & -0.2025 & 0.0216 & -0.1883 & 0.0221 \\
\hline age*gymn: & 0.0015 & 0.0010 & -0.0004 & 0.0004 & -0.0014 & 0.0004 & 0.0008 & 0.0004 & -0.0002 & 0.0003 \\
\hline Age* unive & 0.0113 & 0.0012 & 0.0051 & 0.0005 & 0.0083 & 0.0005 & 0.0061 & 0.0004 & 0.0062 & 0.0004 \\
\hline Big city & 0.0469 & 0.0122 & 0.0911 & 0.0046 & 0.0587 & 0.0046 & 0.0154 & 0.0057 & 0.0444 & 0.0057 \\
\hline Medium ci & 0.0045 & 0.0083 & 0.0142 & 0.0035 & 0.0003 & 0.0033 & 0.0029 & 0.0036 & 0.0033 & 0.0035 \\
\hline \# children & -0.0359 & 0.0030 & & & & & -0.0058 & 0.0011 & 0.0091 & 0.0010 \\
\hline children 0 - & -0.1198 & 0.0075 & & & & & -0.1373 & 0.0023 & -0.0048 & 0.0015 \\
\hline children 3 . & -0.0206 & 0.0041 & & & & & -0.0456 & 0.0016 & -0.0015 & 0.0013 \\
\hline children 7 - & -0.0162 & 0.0023 & & & & & -0.0256 & 0.0012 & 0.0018 & 0.0010 \\
\hline Constant & 9.7271 & 0.1339 & 9.6362 & 0.0618 & 9.6761 & 0.0688 & 9.4884 & 0.0600 & 9.1078 & 0.0698 \\
\hline sigma_u & 0.2925 & & 0.3553 & & 0.3477 & & 0.4786 & & 0.3889 & \\
\hline sigma_e & 0.1017 & & 0.1009 & & 0.1119 & & 0.1242 & & 0.1171 & \\
\hline
\end{tabular}


Table 6. Wage and Taxable income Elasticities for different specifications

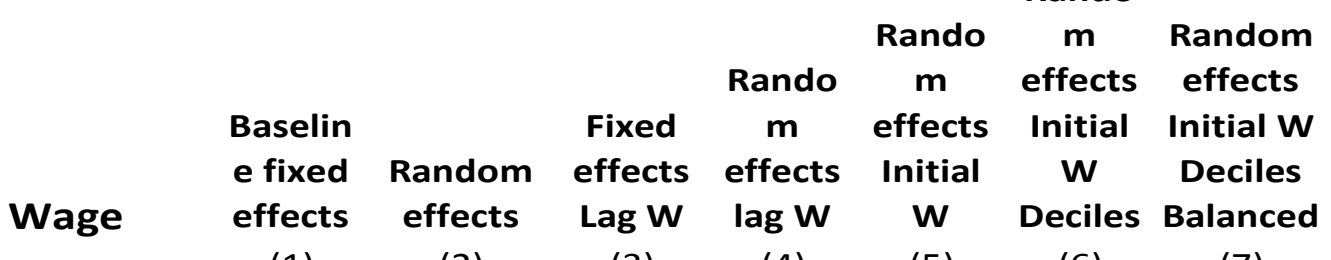

\section{Single}

(1)

(2)

(3)

(4)

(5)

(6)

(7)

\section{Mother}

Net-of-tax

Virtual income

0.093

0.140

0.081

0.100

0.094

0.095

0.088

0.024

0.038

$0.019 \quad 0.024$

$0.028 \quad 0.028$

0.023

Females

Net-of-tax

0.141

0.191

0.088

0.116

0.154

0.153

0.149

Virtual income

0.027

0.037

0.017

0.022

0.030

0.030

0.023

Net-of-tax

0.159

0.241

0.119

0.150

0.178

0.182

0.159

Virtual income

0.038

0.056

0.025

0.033

0.042

0.043

0.038

Females

Net-of-tax

0.010

0.016

0.007

0.017

0.007

0.007

0.009

Virtual income

0.020

0.029

0.011

0.017

0.023

0.022

0.017

\section{Males}

Net-of-tax

0.050

0.069

0.035

0.040

$0.035 \quad 0.034$

0.065

Virtual income

0.058

0.083

0.035

0.041

0.058

0.058

0.072

Taxable incom Baseline Single

\section{Mother}

Net-of-tax

Virtual income

0.419

0.495

0.340

0.350

0.409

0.408

0.361

Females

Net-of-tax

0.112

0.135

0.089

0.094

0.112

0.111

0.095

Virtual income

0.488

0.560

0.345

0.382

0.485

0.483

0.403

0.101

0.117

0.072

0.081

0.102

0.101

0.074

Net-of-tax

0.440

0.516

0.352

0.384

0.430

0.433

0.350

Virtual income

0.102

0.120

0.076

0.083

0.100

0.100

0.079

\section{Females}

Net-of-tax

0.044

0.054

0.037

0.041

0.039

0.038

0.038

Virtual income

0.081

0.090

0.058

0.050

0.073

0.070

0.061

Net-of-tax

Virtual income

0.115

0.131

0.086

0.076

0.087

0.085

0.101

0.145

0.168

0.110

0.099

0.126

0.124

0.131 
Table 7. Effects on the central governmental budget on a reduced state tax

\begin{tabular}{|l|c|c|c|c|}
\hline \multirow{2}{*}{ Macro (billion SEK) } & Static & Labor Supply & Effort & $\begin{array}{c}\text { Total } \\
\text { Effect }\end{array}$ \\
\cline { 2 - 5 } & & & & \\
\cline { 2 - 5 } & & & & \\
\hline Disposable income & 17,6 & 7,3 & 3,4 & 26,9 \\
\hline Tabor income & 0 & 11,1 & 14,6 \\
\hline $\begin{array}{l}\text { VAT (17,6 \% of disposable } \\
\text { income) }\end{array}$ & 3,1 & & & \\
\hline $\begin{array}{l}\text { Pay roll taxes (31,42 \% of } \\
\text { labour income) }\end{array}$ & $-17,6$ & 3,6 & 0,3 & 4,7 \\
\hline Budget effect & 0 & 3,5 & 1,1 & 4,6 \\
\hline \hline Self financing (percent) & $-14,5$ & 8,4 & 2,9 & $-3,3$ \\
\hline $\begin{array}{l}\text { Employment (number of } \\
\text { whole-year equivalences) }\end{array}$ & 0 & 27598 & 0 & 27598 \\
\hline
\end{tabular}




\section{Appendix}

\section{Replicating the wage elasticities in Blomquist and Selin}

As mentioned above, our estimates deviate from the ones presented in Blomquist and Selin, especially for the females - strong incentive effects in Blomquist and Selin compared to essentially zero effects in our study. The main differences between our paper and Blomquist and Selin are the covered time period, the size of the sample as well as the choice of instruments. In order to make our results as comparable as possible, we include two time periods, 1997 and 2007 and use the same method for selecting instruments. However, there still remain important differences - different time period, sample size and source of information used for defining hourly wages.

Blomquist and Selin derive the following statistical model, including parameters $\gamma_{0}, \gamma_{1}$, $\gamma_{2}$ and $\gamma_{3}$.

$$
\begin{aligned}
\ln \left(\frac{\mathrm{W}_{\mathrm{i} 1991}}{\mathrm{~W}_{\mathrm{i} 1981}}\right)= & \gamma_{0}+\gamma_{1} \ln \left(\frac{1-\tau_{\mathrm{i} 1991}}{1-\tau_{\mathrm{i} 1981}}\right)+\gamma_{2} \ln \left(\frac{\mathrm{M}_{\mathrm{i} 1991}}{\mathrm{M}_{\mathrm{i} 1981}}\right)+\gamma_{03} \mathrm{X}_{\mathrm{i} 1981}+\mathrm{f}\left(\ln \overline{\mathrm{TLI}_{1}}\right)+\left(\varepsilon_{\mathrm{i} 1991}\right. \\
& \left.-\varepsilon_{\mathrm{i} 1981}\right)
\end{aligned}
$$

The parameters $\gamma_{1}$ and $\gamma_{2}$ corresponds to the wage elasticity with respect to net-of-tax and virtual income.

Our estimates of this model produce elasticities approximately similar to our earlier results. However our estimates are much lower than the results in Blomquist and Selin. There are many possible explanation of this discrepancy - one important is that our time period does not include the major tax reform 1991.

Table A1. A comparison of wage elasticities

\begin{tabular}{|l|}
\hline Elasticiteter \\
Cohab Male \\
Net-of-tax rate \\
Virtual income \\
Number of observations \\
Cohab females \\
Net-of-tax rate \\
Virtual income \\
Number of observations \\
\hline Single male \\
Net-of-tax rate \\
Virtual income \\
Number of observations \\
\hline Singlefemales \\
Net-of-tax rate \\
Virtual income \\
Number of observations
\end{tabular}

\begin{tabular}{|l|l|}
\hline Blomquist and Selin & Ericson and Flood \\
$0,150 * * *$ & \\
0,007 & $0,048^{* * *}$ \\
586 & $0,135^{* * *}$ \\
& 3687 \\
$0,451 * *$ & 0,011 \\
\hline 0,001 & $0,033^{* * *}$ \\
522 & 5188 \\
& \\
& $0,153^{* * *}$ \\
& $0,044^{* * *}$ \\
& 1243 \\
& $0,069^{* * *}$ \\
& $0,033^{* * *}$ \\
& 2162 \\
\hline
\end{tabular}

